\title{
Synthesis of Thermally Stable Zirconia-Based Mesoporous Materials via a Facile Post-treatment
}

\author{
Shih-Yuan Chen, ${ }^{\dagger}$ Ling-Yun Jang, ${ }^{\dagger}$ and Soofin Cheng $*, \dagger$ \\ Department of Chemistry, National Taiwan University, Taipei 106, Taiwan, Republic of China, and Research \\ Division, National Synchrotron Radiation Research Center, Hsinchu 300, Taiwan, Republic of China
}

Received: January 26, 2006; In Final Form: March 22, 2006

\begin{abstract}
A novel method of preparing thermally stable zirconia-based mesoporous materials was developed. The zirconiabased mesoporous materials of 2D-hexagonal structure were prepared using zirconium sulfate as the zirconium precursor and cetyltrimethylammonium (CTMA) as the pore-directing agent with the aid of salt in the synthesis solution to reduce the sulfate content in the final product and significantly improve the crystallographic ordering. Post-treatment of the mesoporous material with $\mathrm{NaCl}$ solution and lowering the ramping rate to less than 0.2 ${ }^{\circ} \mathrm{C} /$ min during the calcination process, however, were the key steps to hinder the growth of the dense zirconia phase and to retain the ordered mesostructure up to $600{ }^{\circ} \mathrm{C}$. It was found that a portion of the surfactant $(8.9-17.4 \mathrm{wt} \%)$ and sulfate ions $(0.5-1.2 \mathrm{wt} \%)$ were removed during the post-treatment, which prevented the remaining sulfate groups from being reduced by the hydrogen-rich surfactant during the calcination process as confirmed by sulfur K-edge X-ray absorption near edge structure (XANES) and infrared spectroscopy. The maintenance of sulfur in the sulfate state seemed to be important in stabilizing the mesoporous structure of zirconia materials. The mesoporous zirconia materials after extraction with $\mathrm{NaCl}$ solution three times and calcination at $550-600{ }^{\circ} \mathrm{C}$ had the composition $\mathrm{ZrO}_{2-x}\left(\mathrm{SO}_{4}\right)_{x}$ with $x=0.10-0.27$. The material possesses high surface area $\left(\sim 200 \mathrm{~m}^{2} / \mathrm{g}\right)$, large pore volume $\left(\sim 0.10 \mathrm{~cm}^{3} / \mathrm{g}\right)$, and wormlike mesopores. In comparison with the mesoporous zirconia materials stabilized by chemical treatment, the present route was simpler and more environmentally friendly and resulted in mesoporous zirconia materials of better thermal stability.
\end{abstract}

\section{Introduction}

Zirconium oxide is attractive owning to its excellent oxygen conductivity $^{1}$ and its acid-base bifunctional catalytic activities. ${ }^{2}$ Zirconia-based materials of ordered mesoporous structure and high surface area have been synthesized in the past few years based on the surfactant templating routes. ${ }^{3-5}$ In comparison to the mesoporous silica materials, most of the nonsiliceous mesoporous materials have relatively low thermal and hydrothermal stability. The ordered mesoporous structures tend to collapse after the removal of organic templates. In the literature, there have been a few reports on the synthesis of mesoporous zirconia-based materials, but most of them have low thermal stability. ${ }^{6-16}$ In 1996, Hudson and Knowles reported the synthesis of ordered zirconia mesoporous material through a scaffolding mechanism. ${ }^{6}$ The $d$ spacings of the mesoporous zirconia materials were finely tuned by using cationic surfactant with different chain lengths from $\mathrm{C}_{8} \mathrm{TMABr}$ to $\mathrm{C}_{18} \mathrm{TMABr}$. However, the ordered mesostructure collapsed after the materials were calcined at $350{ }^{\circ} \mathrm{C}$. Antonelli and Ying ${ }^{7}$ then developed the ligand-assisted synthesis route based on the coordinative binding of the surfactant headgroup with the metal centers. Mesoporous zirconia materials were synthesized by using surfactants with varied chain length and various headgroups including phosphate, sulfate, amine, and carboxylate. However, the mesoporous structures collapsed after template removal except for the one synthesized with surfactant containing

\footnotetext{
* Corresponding author. Fax: +886-2-2363-6359. E-mail: chem1031@ntu.edu.tw.

National Taiwan University.

National Synchrotron Radiation Research Center.
}

phosphate headgroups. The phosphate group was proposed to enhance the thermal stability due to the formation of a zirconium phosphate layer over the pore wall. Another synthesis method was reported by the groups of Schuth and Stucky, ${ }^{8}$ where zirconium sulfate was used as the precursor and the sulfate group was considered a good counteranion to stabilize the positively charged surfactant head and the multivalent zirconium polyoxo cation. Both the hexagonal P6mm and cubic Ia $3 d$ mesoporous zirconia-based materials were synthesized. However, the mesostructure was stable up to $500{ }^{\circ} \mathrm{C}$ only after post-treatment of the as-made zirconium oxo-sulfate material with a suitable concentration of phosphoric acid. Furthermore, the pore diameters of the resultant materials were less than $2 \mathrm{~nm}$ because the pore wall was coated with a layer of zirconium phosphate (54 wt \%). Recently, Lyu and co-workers ${ }^{12}$ reported the synthesis of mesoporous metal oxide materials with thermal stability up to $550{ }^{\circ} \mathrm{C}$ by using siloxane-containing gemini surfactant as the template. The result was similar to that of phosphatestabilized mesoporous materials, and the pore wall of the mesoporous materials was covered with a layer of silica species formed by oxidation of the siloxane group, as the elemental analysis showed that the $\mathrm{Si} / \mathrm{Zr}$ molar ratio was ca. 0.09 in the calcined samples.

In this paper, we describe the first example of the preparation of zirconia-based mesoporous materials with thermal stability up to $600{ }^{\circ} \mathrm{C}$ through post-treatment of the material synthesized from a zirconium sulfate precursor and cationic $\mathrm{C}_{16} \mathrm{TMABr}$ surfactant. An efficient post-treatment process was developed combining ion exchange and slow ramping rate calcination. The resultant mesoporous materials showed wormlike pores, high 


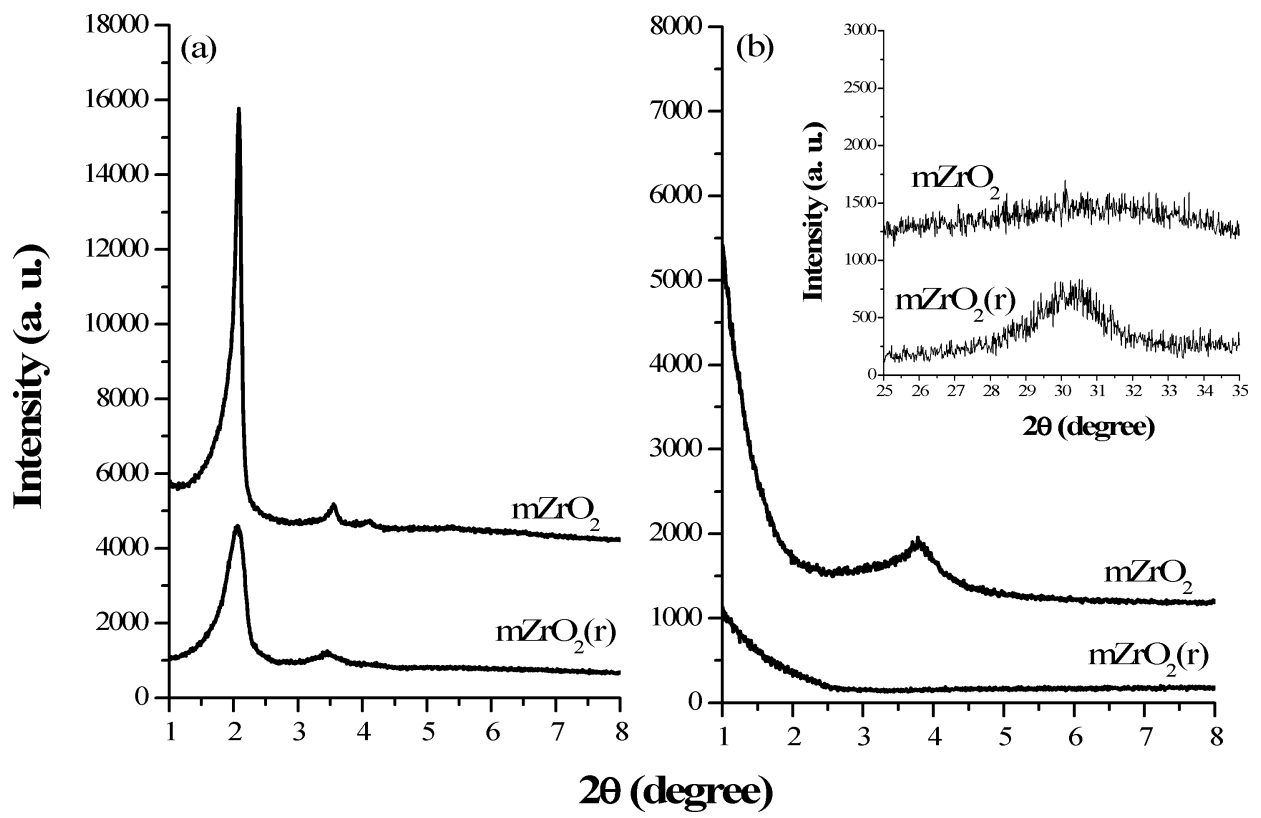

Figure 1. Small- and wide-angle $\mathrm{XRD}$ patterns of (a) as-made and (b) calcined $\left(500{ }^{\circ} \mathrm{C}\right.$ for $\left.3 \mathrm{~h}\right) \mathrm{mZrO}_{2}(\mathrm{r})$ and $\mathrm{mZrO}_{2}$ samples.

surface area, and large pore volume. The effect of residual sulfur species on the thermal stability of mesoporous zirconia materials was investigated.

\section{Experimental Methods}

Synthesis of Mesoporous Zirconia-Based Material. The reported procedure of the synthesis of mesoporous zirconiabased materials $8,17,18$ was modified by introducing salts into the synthesis solutions. Generally, $2.51 \mathrm{~g}$ of cetyltrimethylammonium bromide (CTMABr, Acros) as pore-directing agent and $3.74 \mathrm{~g}$ of sodium chloride (Acros) were dissolved in $85 \mathrm{~g}$ of deionized water. Then, $25 \mathrm{~g}$ of aqueous solution containing 4.55 $\mathrm{g}$ of zirconium sulfate $\left(\mathrm{Zr}\left(\mathrm{SO}_{4}\right)_{2} \cdot 4 \mathrm{H}_{2} \mathrm{O}\right.$, Aldrich) was added in slowly, where the $\mathrm{NaCl} / \mathrm{Zr}$ molar ratio was 5 . A white precipitate appeared after ca. $15 \mathrm{~mL}$ of zirconium sulfate solution was added. The mixed solution was stirred at $35^{\circ} \mathrm{C}$ for 1 day, then sealed in a polypropylene bottle and heated at $100{ }^{\circ} \mathrm{C}$ under static conditions for 2 days. The solid product was recovered by filtering, washing with $300 \mathrm{~mL}$ of deionized water, and drying at $50{ }^{\circ} \mathrm{C}$ overnight. The compositions of reactants were $1 \mathrm{Zr}\left(\mathrm{SO}_{4}\right)_{2} \cdot 4 \mathrm{H}_{2} \mathrm{O}: 0.5$ CTMABr:5 NaCl: $477 \mathrm{H}_{2} \mathrm{O}$. The as-made material was named $\mathrm{mZrO}_{2}$. A reference sample named $\mathrm{mZrO}_{2}-$ (r) was also prepared without the addition of $\mathrm{NaCl}$ in the synthesis solution.

Post-treatment. Post-treatment with aqueous $\mathrm{NaCl}$ solution and calcination, noted as the soft and hard methods, respectively, were used to remove the surfactant from the as-made materials. Generally, about $4 \mathrm{~g}$ of the as-made material in powder form was dispersed in $400 \mathrm{~mL}$ of $0.5 \mathrm{M} \mathrm{NaCl}$ solution, and the suspension was stirred for 1 day. The solid product was recovered by filtering, washing with a large amount of deionized water, and drying at $50{ }^{\circ} \mathrm{C}$ overnight. This procedure was repeated several times. Calcination was performed in air atmosphere. The oven temperature was raised from room temperature to the desired calcination temperature with a ramping rate less than $0.2{ }^{\circ} \mathrm{C} / \mathrm{min}$, and the final calcination temperature was retained for $3 \mathrm{~h}$. The post-treated materials were named $\mathrm{mZrO}_{2}-\mathrm{S}-x$, where " $\mathrm{S}$ " refers to post-treatment with a $0.5 \mathrm{M} \mathrm{NaCl}$ solution for $x$ times. The calcined materials were named $\mathrm{C} y$ - $\mathrm{mZrO}_{2}-\mathrm{S}-x$, where " $\mathrm{C}$ " refers to calcination and $y$ is the calcination temperature in degrees Celsius.
Characterization. X-ray diffraction (XRD) patterns were recorded on a Philip X'pert Pro diffractometer with $\mathrm{Cu} \mathrm{K \alpha}$ radiation operated at $40 \mathrm{~mA}$ and $45 \mathrm{kV}$. The pore structures of the materials were analyzed by nitrogen physical sorption at liquid nitrogen temperature ( $77 \mathrm{~K}$ ) using a Micrometerics TriStar 3000 system. Prior to the experiments, the materials were outgassed at $200-400{ }^{\circ} \mathrm{C}$ for $6-8 \mathrm{~h}$ under vacuum $\left(10^{-3}\right.$ Torr $)$. The sulfur K-edge X-ray absorption near edge spectra (XANES) were recorded at the beam line 15B of National Synchrotron Radiation Research Center in Hsinchu, Taiwan. Standard operating conditions were $1.5 \mathrm{GeV}$ and 120-200 mA. The photon energy was calibrated using the L-edge of pure Mo foil. The scanning electron microscopy (SEM) images were taken using a Hitachi S-800 field emission scanning electron microscope. The transmission electron microscope (TEM) experiments were performed using a Hitachi H-7100 transmission electron microscope over the sliced specimen of ca. $90 \mathrm{~nm}$ in thickness. The thermal analyses including thermogravimetric analysis (TGA), differential scanning calorimetry (DSC), and evolved gas mass analysis were carried out using a Netzch STA-409CD system with a ramp rate of $10^{\circ} \mathrm{C} / \mathrm{min}$ in an air flow of $50 \mathrm{~mL} /$ min. The elemental analysis of $\mathrm{C}, \mathrm{H}, \mathrm{N}$, and $\mathrm{S}$ was measured using a Heraeus VarioEL instrument. FT-IR spectra were recorded using a BOMEM DA 3.02 spectrometer with a resolution of $2 \mathrm{~cm}^{-1}$.

\section{Results and Discussion}

XRD Patterns of Zirconia-Based Mesoporous Materials. Well-ordered zirconia-based mesoporous materials were synthesized by adding proper amounts of salts in the synthesis solutions. Figure 1 compares the XRD patterns of the materials synthesized with and without $\mathrm{NaCl}$. The (100), (110), and (200) peaks of the hexagonal $P 6 \mathrm{~mm}$ arranged pore structure were much sharper and more clearly seen on the as-made $\mathrm{mZrO}_{2}$ material than that of the reference material $\mathrm{mZrO}_{2}(\mathrm{r})$, suggesting that the mesopore ordering in the as-made $\mathrm{mZrO}_{2}$ was better than that synthesized without $\mathrm{NaCl}$. The optimal amount of sodium chloride used in the synthesis was found to be ca. 3-5 for the $\mathrm{NaCl} / \mathrm{Zr}$ molar ratio. Organic salts including benzyltrimethylammonium chloride (BTMACl), tetraethylammonium chloride (TEACl), and tetrapropylammonium bromide (TPABr) 


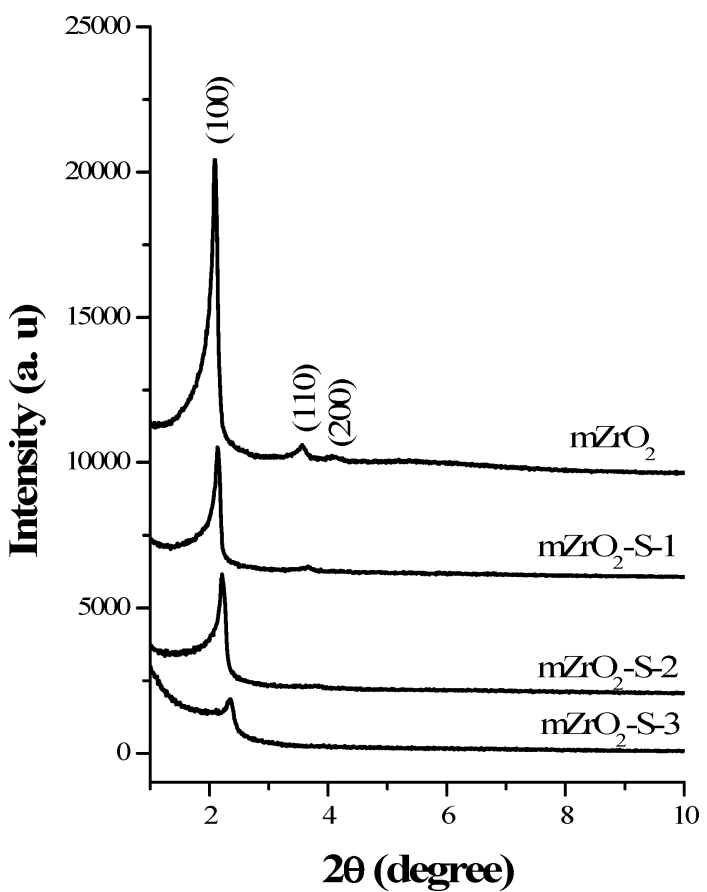

Figure 2. Small-angle XRD patterns of the $\mathrm{mZrO}_{2}-\mathrm{S}-x$ samples.

and inorganic salts such as $\mathrm{NaBr}$ were found to have an effect similar to $\mathrm{NaCl}$, but $\mathrm{Na}_{2}\left(\mathrm{SO}_{4}\right)$ would interfere with mesopore ordering. To the best of our knowledge, this is the first example of applying salts in the synthesis to improve the pore ordering of nonsiliceous mesoporous materials. Among the salts, the effect of $\mathrm{NaCl}$ was most obvious, and it is also the most economical and least hazardous salt used.

The addition of salt was found to increase the thermal stability of mesostructured $\mathrm{ZrO}_{2}$ slightly. Figure $1 \mathrm{~b}$ shows that the sample calcined at $500{ }^{\circ} \mathrm{C}$ (termed $\mathrm{C} 500-\mathrm{mZrO}_{2}$ ) retains a weak diffraction at $2 \theta \sim 3.8^{\circ}$, while the reference material has no diffraction peak in the small-angle region. In the high-angle region, a broad peak around $2 \theta \sim 30.5^{\circ}$ corresponding to the crystalline $\mathrm{ZrO}_{2}$ phase was observed on the calcined reference material, but no peak was observed on C500- $\mathrm{mZrO}_{2}$. This demonstrates that although template removal from mesostructured $\mathrm{ZrO}_{2}$ material by calcination would destroy the mesopores, the sample synthesized with $\mathrm{NaCl}$ could still retain the ordering of the mesostructure slightly after calcination at $500{ }^{\circ} \mathrm{C}$.

In comparison to high-temperature calcination, extraction by solvent is a relatively soft method and an alternative path to remove the surfactant species from the mesoporous materials. ${ }^{19}$ Hereafter, the extraction treatment was carried out on the mesostructured zirconia materials synthesized with $\mathrm{NaCl}$ because better crystallographic ordering was observed on the asmade samples. In a preliminary experiment, the mesoporous structure was found to collapse after the sample was extrated with a boiling ethanol solution for $30 \mathrm{~min}$. This implies that the mesostructure is very sensitive to the removal of the CTMA surfactant, and the extraction rate was probably too fast by using boiling ethanol. Accordingly, a mild extraction method was developed by using aqueous $\mathrm{NaCl}$ solution as the extraction agent. By varying the concentration of the $\mathrm{NaCl}$ solution, it was found that the optimal concentration of $\mathrm{NaCl}$ around $0.5 \mathrm{M}$ was needed in order to retain the mesostructure after $550{ }^{\circ} \mathrm{C}$ calcination. Above this concentration, the mesostructure would collapse after extraction due to too much surfactant being removed. Below this concentration, the efficiency of surfactant removal was poor and the mesostructure also collapsed after calcination.
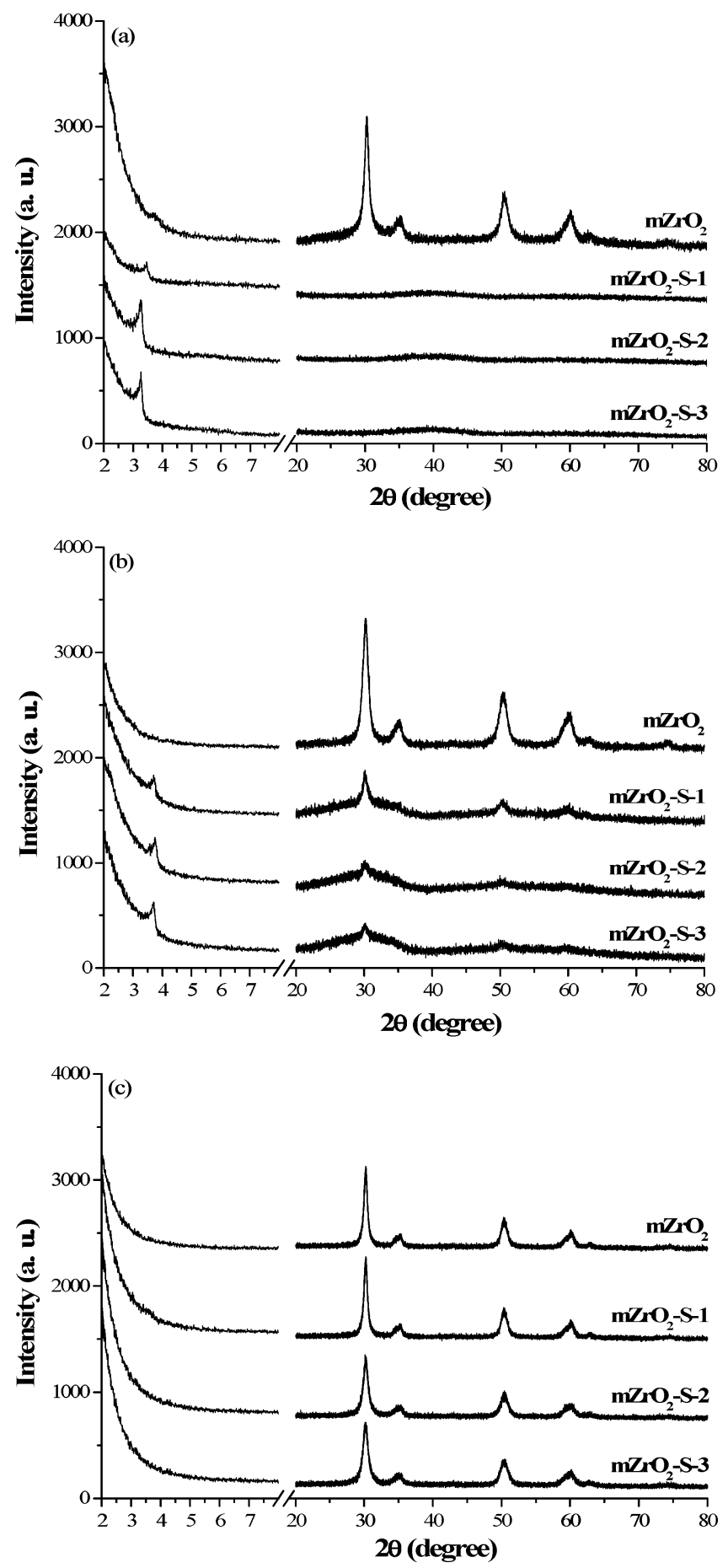

Figure 3. Small- and wide-angle $\mathrm{XRD}$ patterns of $\mathrm{mZrO}_{2}$ and $\mathrm{mZrO}_{2}-$ S- $x$ samples calcined at (a) $550{ }^{\circ} \mathrm{C}$, (b) $600{ }^{\circ} \mathrm{C}$, and (c) $650{ }^{\circ} \mathrm{C}$.

The small-angle XRD patterns of mesostructured zirconia before and after extraction with $\mathrm{NaCl}$ solution are shown in Figure 2. In comparison to the as-made $\mathrm{mZrO}_{2}$, the intensity of the (100) peak decreased and the (110) and (200) diffraction peaks gradually disappeared with the increase in the number of extractions. The $d_{(100)}$ also shifted toward smaller spacings from the original value of $42.1 \AA$ to $41.4,39.9$, and $37.6 \AA$ after for one, two, and three extractions, respectively. The structural contraction in (100) was ca. $10 \%$ after the as-made $\mathrm{mZrO}_{2}$ was extracted with $\mathrm{NaCl}$ solution three times.

The XRD patterns of the calcined zirconia-based materials are shown in Figure 3. All the extracted samples retained a diffraction peak in the low-angle region of $2 \theta \sim 3-4^{\circ}$, corresponding to $d_{(100)}$ spacings of $25.5,26.9$, and $27.1 \AA$ for C550- 
TABLE 1: Textural Properties of Calcined Zirconia-Based Materials

\begin{tabular}{|c|c|c|c|c|}
\hline material $^{a}$ & $S_{\text {BET }}\left(\mathrm{m}^{2} / \mathrm{g}\right)$ & $V_{\text {Total }}\left(\mathrm{cm}^{3} / \mathrm{g}\right)$ & $\Phi^{b}(\mathrm{~nm})$ & $W_{\mathrm{t}}^{c}(\mathrm{~nm})$ \\
\hline $\mathrm{C} 550-\mathrm{mZrO}_{2}(\mathrm{r})$ & 20 & 0.010 & & \\
\hline $\mathrm{C} 550-\mathrm{mZrO}_{2}$ & 15 & 0.007 & & \\
\hline $\mathrm{C} 550-\mathrm{mZrO}_{2}-\mathrm{S}-1$ & 89 & 0.052 & $1.1(<2)$ & 1.5 \\
\hline $\mathrm{C} 550-\mathrm{mZrO}_{2}-\mathrm{S}-2$ & 185 & 0.089 & $1.5(<2)$ & 1.4 \\
\hline $\mathrm{C} 550-\mathrm{mZrO}_{2}-\mathrm{S}-3$ & 225 & 0.108 & $1.8(\sim 2.0)$ & 1.1 \\
\hline $\mathrm{C} 600-\mathrm{mZrO}_{2}-\mathrm{S}-1$ & 98 & 0.061 & $1.9(2.4)$ & 1.0 \\
\hline $\mathrm{C} 600-\mathrm{mZrO}_{2}-\mathrm{S}-2$ & 201 & 0.121 & $1.9(2.1)$ & 1.1 \\
\hline $\mathrm{C} 600-\mathrm{mZrO}_{2}-\mathrm{S}-3$ & 239 & 0.151 & $2.2(2.3)$ & 1.0 \\
\hline $\mathrm{C} 650-\mathrm{mZrO}_{2}-\mathrm{S}-1$ & 93 & 0.066 & $2.9(3.1)$ & \\
\hline $\mathrm{C} 650-\mathrm{mZrO}_{2}-\mathrm{S}-2$ & 144 & 0.100 & $3.0(3.2)$ & \\
\hline $\mathrm{C} 650-\mathrm{mZrO}_{2}-\mathrm{S}-3$ & 142 & 0.104 & $2.9(3.1)$ & \\
\hline
\end{tabular}

${ }^{a}$ All materials are calcined with a ramping rate of $0.1{ }^{\circ} \mathrm{C} / \mathrm{min} .{ }^{b} \mathrm{BJH}$ average pore diameter from desorption profile. The numbers in parentheses are the pore diameter at maximum pore volume. ${ }^{c}$ Wall thicknesses are measured by $W_{\mathrm{t}}=a-\Phi$, where $a=2\left(d_{(100)} / \sqrt{ } 3\right)$. $\mathrm{mZrO}_{2}-\mathrm{S}-1$, C550- $\mathrm{mZrO}_{2}-\mathrm{S}-2$, and C550- $\mathrm{mZrO}_{2}-\mathrm{S}-3$, respectively. This reveals that the ordered mesostructure was still present after $550{ }^{\circ} \mathrm{C}$ calcination. It is also noticeable that no diffraction peaks appear in the wide-angle region, implying that no dense crystal phases of zirconia were formed when the materials were extracted with $\mathrm{NaCl}$ of proper concentration before calcination. In contrast, the mesostructure collapsed and the tetragonal $\mathrm{ZrO}_{2}$ phase with an average crystallite size of ca. $11.6 \mathrm{~nm}$ was formed if the $\mathrm{NaCl}$ extraction was not carried out before calcining the samples at $550{ }^{\circ} \mathrm{C}$.

The XRD patterns of the samples calcined at $600{ }^{\circ} \mathrm{C}(\mathrm{C} 600-$ $\mathrm{mZrO}_{2}-\mathrm{S}-x$ ) were similar to those calcined at $550{ }^{\circ} \mathrm{C}$, except the diffraction peaks in the low-angle region became less intense and those of the tetragonal $\mathrm{ZrO}_{2}$ phase in the high-angle region started appearing. Moreover, the peak intensity of tetragonal $\mathrm{ZrO}_{2}$ decreased with the number of $\mathrm{NaCl}$ extractions. These results imply that two or three $\mathrm{NaCl}$ extractions were necessary in order to retain the thermal stability of mesostructured $\mathrm{ZrO}_{2}$ material up to $600{ }^{\circ} \mathrm{C}$.

When the calcination temperature was further raised to 650 ${ }^{\circ} \mathrm{C}$, all the low-angle diffraction peaks disappeared, while those of the tetragonal $\mathrm{ZrO}_{2}$ phase became very sharp. These results demonstrated that the $\mathrm{mZrO}_{2}$ samples post-treated with $\mathrm{NaCl}$ solution could retain the mesostructure up to $600{ }^{\circ} \mathrm{C}$, but they converted completely to the tetragonal phase at $650{ }^{\circ} \mathrm{C}$.

Physical Properties. The texture properties of the calcined mesoporous zirconia samples are shown in Table 1. The BET surface areas and pore volumes of the samples calcined at 550 ${ }^{\circ} \mathrm{C}$ without $\mathrm{NaCl}$ extraction treatment were very small, $15-20$ $\mathrm{m}^{2} / \mathrm{g}$ and $<0.01 \mathrm{~cm}^{3} / \mathrm{g}$, respectively. Post-treating the as-made mesoporous zirconia samples with $\mathrm{NaCl}$ solutions increased dramatically the surface area and pore volume. Moreover, two or three extractions were more effective in increasing the surface area and pore volume than just one. Surface areas greater than $200 \mathrm{~m}^{2} / \mathrm{g}$ and pore volumes larger than $0.10 \mathrm{~cm}^{3} / \mathrm{g}$ were obtained for the samples extracted with $\mathrm{NaCl}$ solution two or three times and then calcined at $550-600{ }^{\circ} \mathrm{C}$. The surface area decreased to around $140 \mathrm{~m}^{2} / \mathrm{g}$, but pore volume still remained around 0.10 $\mathrm{cm}^{3} / \mathrm{g}$ when the calcination temperature was raised to $650{ }^{\circ} \mathrm{C}$. These results suggest that the optimal condition for obtaining mesoporous zirconia of high surface area $\left(\sim 200 \mathrm{~m}^{2} / \mathrm{g}\right)$, large pore volume $\left(\sim 0.10 \mathrm{~cm}^{3} / \mathrm{g}\right)$, and relatively large pore diameter (ca. $2.2 \mathrm{~nm}$ ) was by extracting the material with $\mathrm{NaCl}$ solution three times before calcination at $550-600{ }^{\circ} \mathrm{C}$. In comparison to the literature reports on phosphate- and silica-stabilized zirconia mesoporous materials, $8,9,12$ the $\mathrm{NaCl}$ extraction method in the present study is more environmentally friendly and of lower cost.
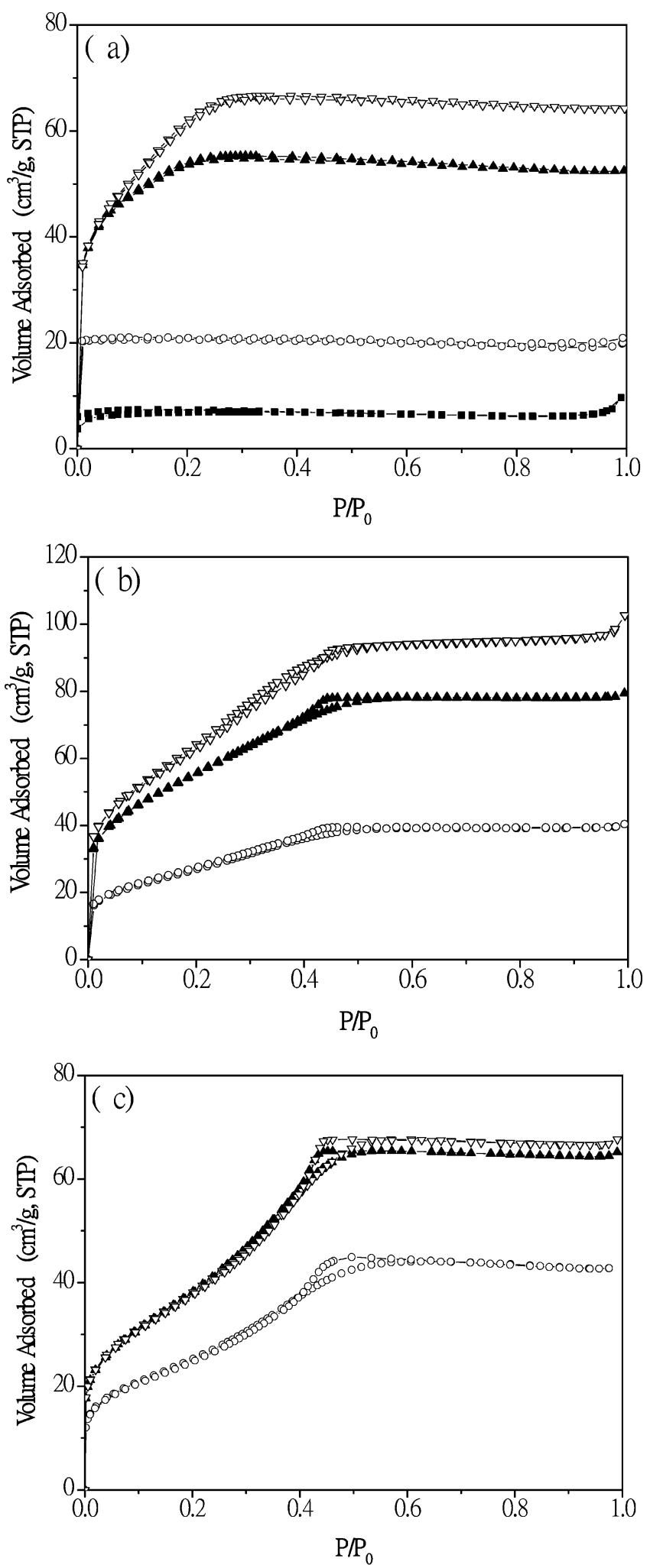

Figure 4. $\mathrm{N}_{2}$ adsorption-desorption isotherms of $\mathrm{mZrO}_{2}$ (solid squares), $\mathrm{mZrO}_{2}-\mathrm{S}-1$ (empty circles), $\mathrm{mZrO}_{2}-\mathrm{S}-2$ (solid triangles), and $\mathrm{mZrO}_{2}-\mathrm{S}-3$ (empty inverted triangles) samples calcined at (a) $550{ }^{\circ} \mathrm{C}$, (b) $600{ }^{\circ} \mathrm{C}$, and (c) $650{ }^{\circ} \mathrm{C}$

The nitrogen sorption isotherms of calcined mesoporous $\mathrm{ZrO}_{2}$ samples are shown in Figure 4. The shapes of the isotherms were found to change with calcination temperature. For the samples calcined at $550{ }^{\circ} \mathrm{C}$, type I isotherms (Langmuir type) corresponding to microporous materials were observed. Moreover, the adsorbed volume of nitrogen increased with the number of $\mathrm{NaCl}$ extractions, and the value was negligible for the sample 

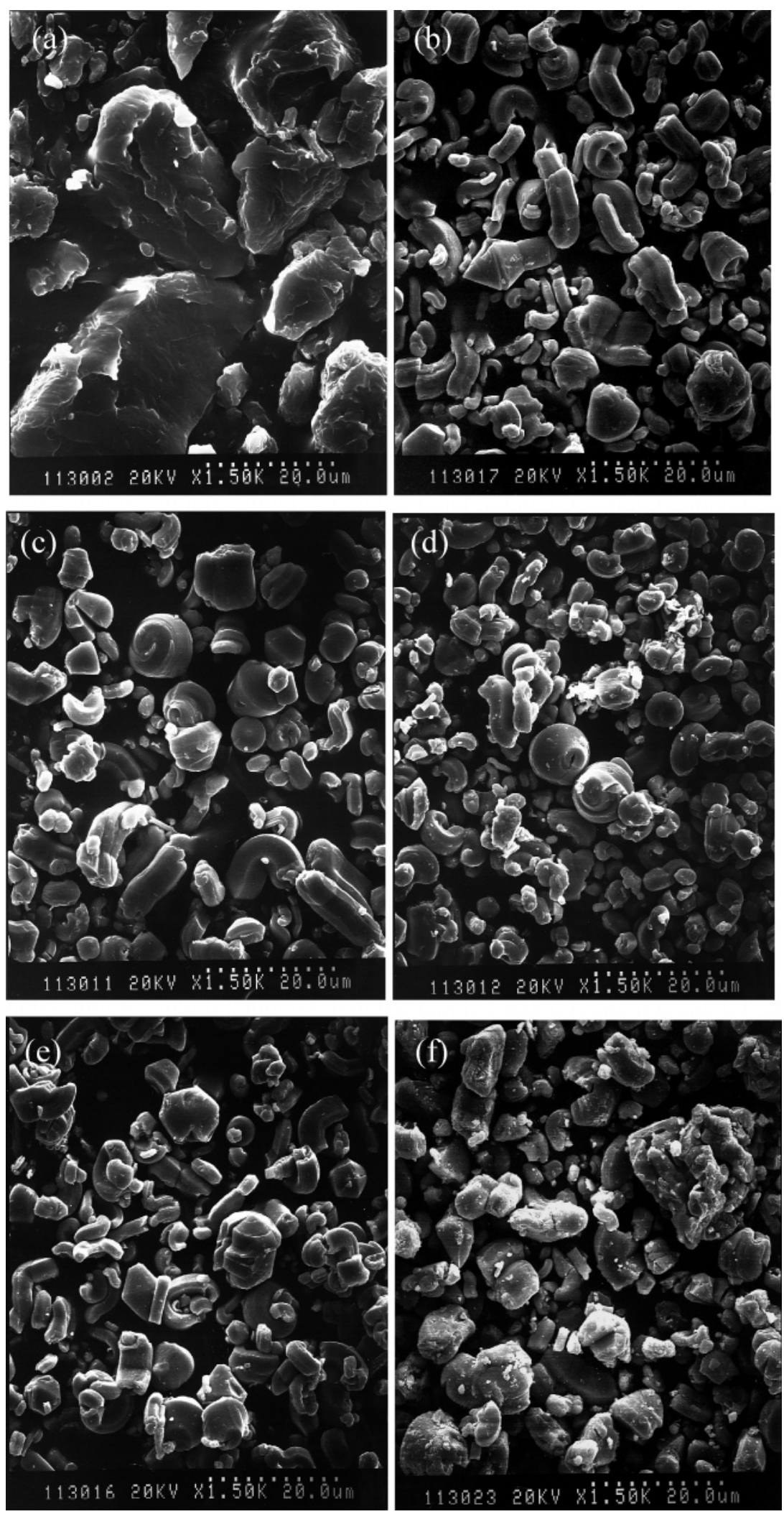

Figure 5. SEM photographs of (a) $\mathrm{mZrO}_{2}$ (r), (b) $\mathrm{mZrO}_{2}$, (c) $\mathrm{mZrO}_{2}-\mathrm{S}-3$, and $\mathrm{mZrO}_{2}-\mathrm{S}-3$ calcined at (d) $550{ }^{\circ} \mathrm{C}$, (e) $600{ }^{\circ} \mathrm{C}$, and (f) $650{ }^{\circ} \mathrm{C}$.

C550- $\mathrm{mZrO}_{2}$, which was not extracted with $\mathrm{NaCl}$. When the calcination temperature was higher than $600{ }^{\circ} \mathrm{C}$, type IV isotherms with the capillary condensation at $P / P_{0}$ around $0.2-$ 0.5 were seen. Since the color of the samples C $550-\mathrm{mZrO}_{2}$ and C550- $\mathrm{mZrO}_{2}-\mathrm{S}-1$ was yellowish to pale brown, while those calcined at higher temperatures were pure white, the microporous character of the samples calcined at $550{ }^{\circ} \mathrm{C}$ is probably due to the blockage of the mesopores by the residual carbon or sulfur species. Similar phenomena were also reported on the phosphate-stabilized zirconia-based materials, especially in the materials with cagelike pore structures. ${ }^{8,9}$

Electron Microscopy. The SEM images of the as-made mesostructured zirconia that was extracted with $\mathrm{NaCl}$ solution three times and that was calcined at various temperatures are shown in Figure 5. The morphology of as-made $\mathrm{mZrO}_{2}(\mathrm{r})$ synthesized without salt was irregular, and the particle size was 

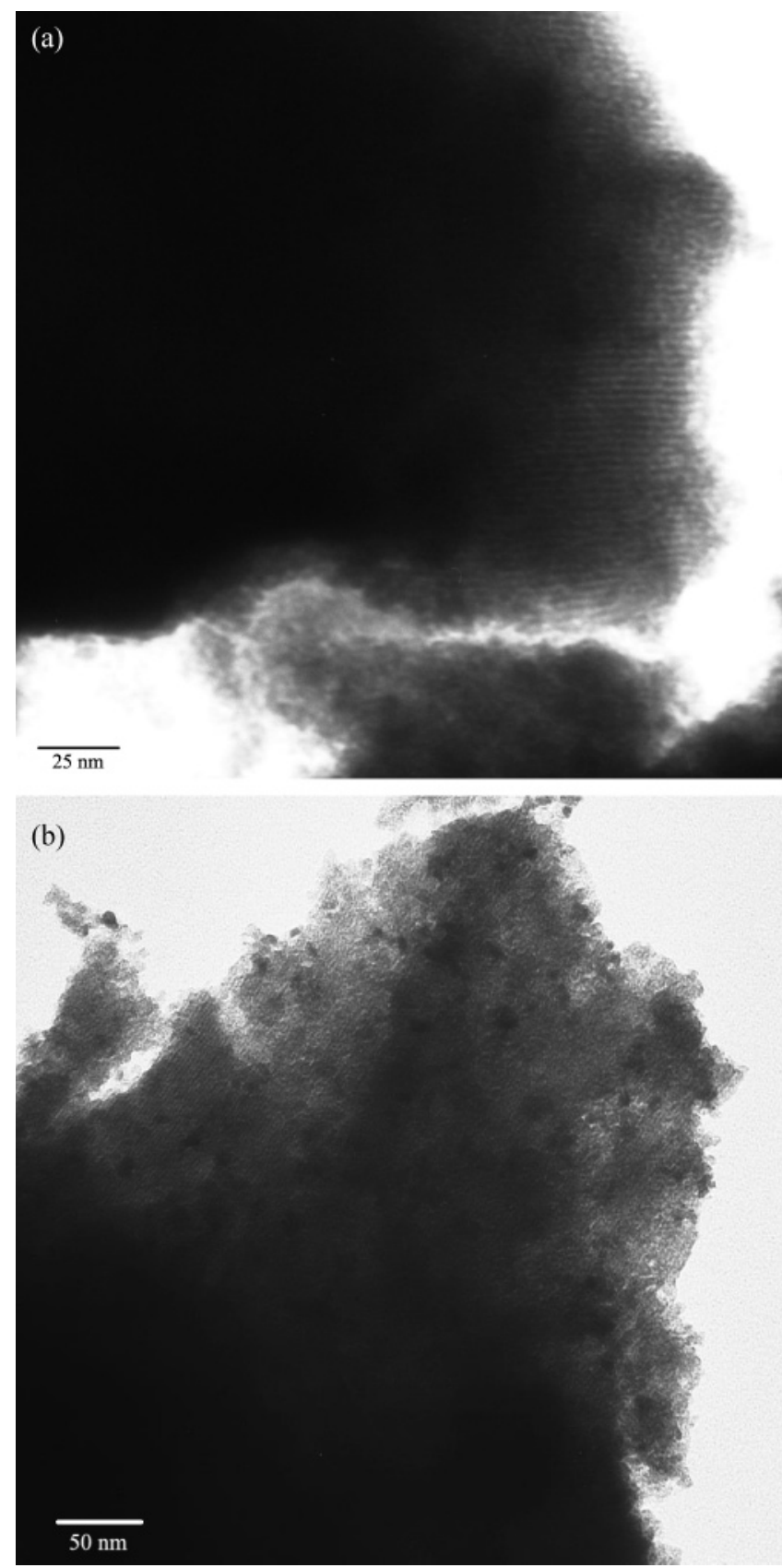

Figure 6. TEM photos of (a) C550- $\mathrm{mZrO}_{2}-\mathrm{S}-3$ and (b) $\mathrm{C} 600-\mathrm{mZrO}_{2-}$ S-3 samples.

randomly distributed in the $2-50 \mu \mathrm{m}$ range. On the contrary, $\mathrm{mZrO}_{2}$, which was synthesized with $\mathrm{NaCl}$, has more ordered morphologies of twisted rods and whirligigs. The sizes of the twisted rods and whirligigs were ca. $2-10 \mu \mathrm{m}$, and the surfaces were relatively smooth. Moreover, the particle size and morphology of $\mathrm{mZrO}_{2}$ did not change significantly upon extraction with $\mathrm{NaCl}$ solution or after calcination up to $600^{\circ} \mathrm{C}$. Only when the calcination temperature was raised to $650{ }^{\circ} \mathrm{C}$ were many smaller particles of $<1 \mu \mathrm{m}$ seen covering the surfaces of large particles.

The TEM photographs of calcined samples C550- $\mathrm{mZrO}_{2}-\mathrm{S}-3$ and $\mathrm{C} 600-\mathrm{mZrO}_{2}-\mathrm{S}-3$ are shown in Figure 6. The ordered channeling mesopores could be clearly seen. However, some dark particles with diameters in the $5-10 \mathrm{~nm}$ range can also be seen on the sample calcined at $600{ }^{\circ} \mathrm{C}$ in Figure 6b. They are probably attributed to the semicrystalline zirconia particles formed at $600{ }^{\circ} \mathrm{C}$, since its XRD pattern in Figure $3 \mathrm{~b}$ shows small diffraction peaks corresponding to tetragonal $\mathrm{ZrO}_{2}$. The pore diameter and wall thickness measured from the TEM images were both ca. $1.5-2 \mathrm{~nm}$. These results are consistent with the data obtained from physical sorption of $\mathrm{N}_{2}$.

Infrared Spectroscopy. The infrared spectra of $\mathrm{mZrO}_{2}$ samples before and after $\mathrm{NaCl}$ extraction as well as those after calcination are shown in Figure 7. The absorption bands of asmade $\mathrm{mZrO}_{2}$ and those after $\mathrm{NaCl}$ extraction were similar, except that the intensity of the peaks related to CTMA surfactant decreased gradually with the increase in the number of extractions. These peaks include the $\mathrm{C}-\mathrm{H}$ stretching and $\mathrm{CH}_{2}$ scissoring vibrations in the regions 2853-2922 and 1464-1489 $\mathrm{cm}^{-1}$, respectively, and the $\mathrm{C}-\mathrm{N}$ stretching vibration around $1226 \mathrm{~cm}^{-1}$. Moreover, the vibrational band of the sulfate group in the region $900-1400 \mathrm{~cm}^{-1}$ also decreased slightly in intensity as the number of extractions increased.

After the mesoporous zirconia materials were calcined at 550 ${ }^{\circ} \mathrm{C}$, all the vibrational bands corresponding to the surfactant disappeared, indicating that the surfactant was nearly removed by calcination. The IR spectrum of $\mathrm{C} 550-\mathrm{mZrO}_{2}$ shows a strong $\mathrm{Zr}-\mathrm{O}$ stretching band covering $400-800 \mathrm{~cm}^{-1}$ and several small absorption bands, which were assigned to the sulfate group in the $900-1400 \mathrm{~cm}^{-1}$ region and the stretching and bending vibrations of hydroxyl groups at 3430 and $1640 \mathrm{~cm}^{-1}$, respectively. In contrast, the calcined samples with $\mathrm{NaCl}$ pre-extraction such as $\mathrm{C} 550-\mathrm{mZrO}_{2}-\mathrm{S}-3$ showed a doublet feature of a $\mathrm{Zr}-\mathrm{O}$ stretching band in the $400-800 \mathrm{~cm}^{-1}$ region, which is akin to that of as-made and $\mathrm{NaCl}$-extracted samples. In addition, there were strong bands around $3000-3600 \mathrm{~cm}^{-1}$ attributed to the adsorbed water with hydrogen bonding and strong peaks at 900-1400 $\mathrm{cm}^{-1}$ for sulfate groups. This implies that large amounts of sulfate ions were still retained in C550- $\mathrm{mZrO}_{2}-\mathrm{S}-3$ and the surface of this calcined sample was very hydrophilic, in contrast to that of $\mathrm{C} 550-\mathrm{mZrO}_{2}$. Moreover, the intensity of these peaks did not vary significantly with the number of $\mathrm{NaCl}$ extractions (not shown), and the bands at 900-1400 and 3000$3600 \mathrm{~cm}^{-1}$ weakened only slightly when increasing the calcination temperature to $600{ }^{\circ} \mathrm{C}$. However, these peaks shrank markedly and the doublet band of $\mathrm{Zr}-\mathrm{O}$ stretching at 400$800 \mathrm{~cm}^{-1}$ merged to one when the calcination temperature was further raised to $650{ }^{\circ} \mathrm{C}$. These results imply that a large portion of the sulfate groups was removed at $650^{\circ} \mathrm{C}$ and the surface of resultant material became less hydrophilic. Since the XRD studies showed that the mesostructure collapsed and a dense $\mathrm{ZrO}_{2}$ phase was formed after calcining the materials at $650{ }^{\circ} \mathrm{C}$, it is therefore proposed that the residual sulfate groups may contribute to the thermal stability of the mesoporous zirconia materials.

Elemental and Thermal Analysis. The results of elemental and thermal gravimetric (TG) analysis are shown in Table 2. There was ca. $7 \%$ sulfur (or a $\mathrm{S} / \mathrm{Zr}$ molar ratio of ca. 0.5 ) in the as-made mesoporous zirconia materials. Moreover, the sample synthesized with the aid of $\mathrm{NaCl}$ had lower $\mathrm{S}$ content than that synthesized without $\mathrm{NaCl}$. Extraction of the as-made mesoporous zirconia material with $\mathrm{NaCl}$ solution also decreased the $\mathrm{S}$ content gradually with increasing the number of extractions. After extracting the material three times, the S/Zr molar ratio decreased from 0.48 to 0.28 .

Calcination reduced the $\mathrm{S}$ content markedly, and the $\mathrm{S} / \mathrm{Zr}$ ratio decreased with the increase in calcination temperature. However, it is noticeable that the samples post-treated with $\mathrm{NaCl}$ solutions did not lose as much sulfur as those without $\mathrm{NaCl}$ extraction. The $\mathrm{S} / \mathrm{Zr}$ ratios were $0.23-0.27$ for the $\mathrm{NaCl}-$ extracted samples calcined at $550{ }^{\circ} \mathrm{C}$, while that without extraction was 0.07 . At a calcination temperature of $600{ }^{\circ} \mathrm{C}$, 

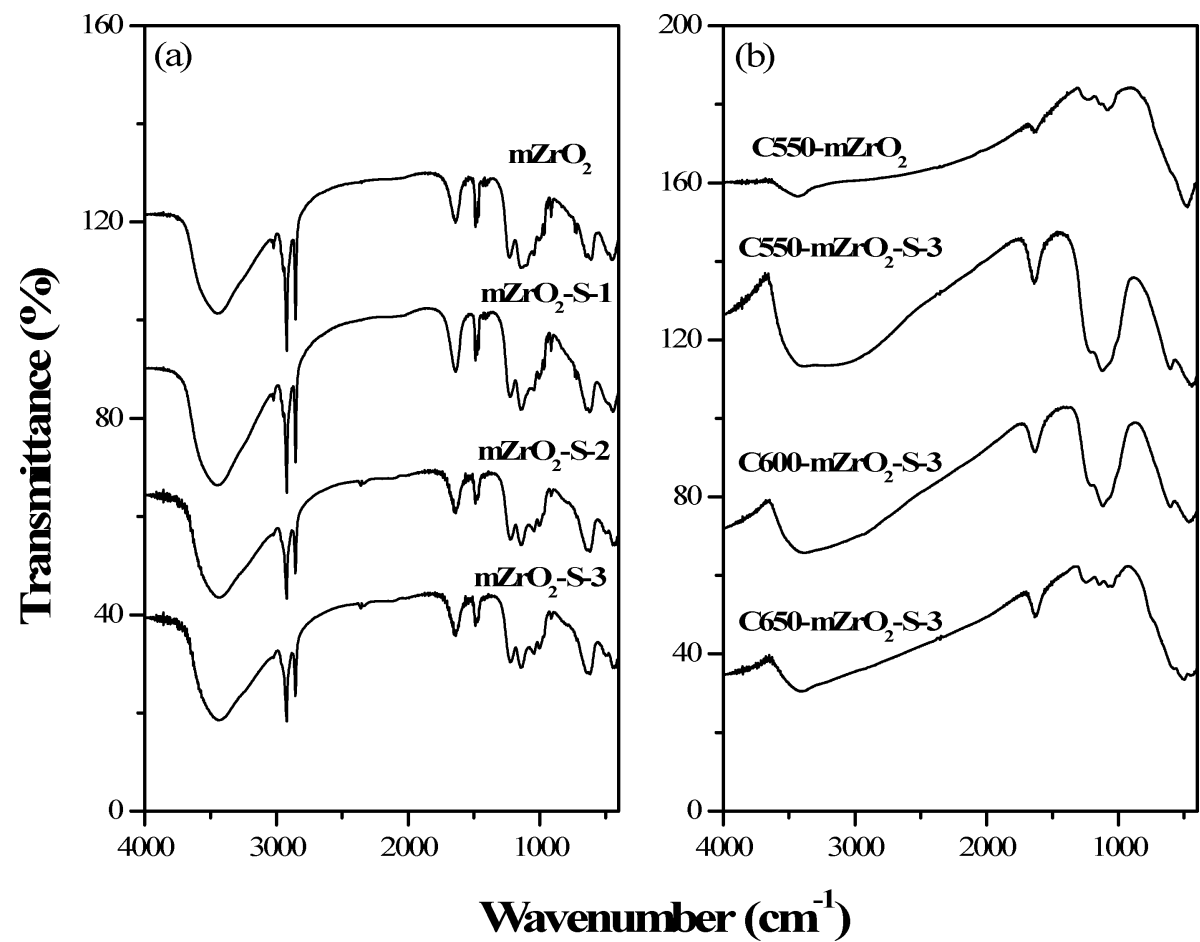

Figure 7. IR spectra of (a) as-made and $\mathrm{NaCl}$-extracted as well as (b) calcined zirconia-based mesoporous materials.

TABLE 2: Elemental and TG Analysis Data of Zirconia-Based Mesoporous Materials

\begin{tabular}{|c|c|c|c|c|c|c|c|c|c|}
\hline \multirow[b]{2}{*}{ sample $^{a}$} & \multicolumn{4}{|c|}{ elemental analysis (wt \%) } & \multicolumn{2}{|c|}{$\mathrm{S} / \mathrm{Zr}(\mathrm{mol})$} & \multirow[b]{2}{*}{$\mathrm{wt}$ loss $(\mathrm{wt} \%)^{b}$} & \multirow[b]{2}{*}{$\mathrm{H}_{2} \mathrm{O}(\mathrm{wt} \%)^{c}$} & \multirow[b]{2}{*}{$\mathrm{SO}_{4}{ }^{2-}(\mathrm{wt} \%)^{d}$} \\
\hline & $\mathrm{S}$ & $\mathrm{C}$ & $\mathrm{N}$ & $\mathrm{H}$ & EA & TG & & & \\
\hline $\mathrm{mZrO}_{2}(\mathrm{r})$ & 7.34 & 32.31 & 1.84 & 6.67 & 0.55 & & 69.0 & & \\
\hline $\mathrm{mZrO}_{2}$ & 6.93 & 29.00 & 1.65 & 6.43 & 0.48 & & 66.2 & & \\
\hline $\mathrm{mZrO}_{2}-\mathrm{S}-1$ & 6.45 & 24.28 & 1.29 & 5.83 & 0.42 & & 57.3 & & \\
\hline $\mathrm{mZrO}_{2}-\mathrm{S}-2$ & 5.91 & 21.53 & 1.14 & 5.48 & 0.32 & & 53.9 & & \\
\hline $\mathrm{mZrO}_{2}-\mathrm{S}-3$ & 5.70 & 15.96 & 0.73 & 4.66 & 0.28 & & 48.8 & & \\
\hline $\mathrm{C} 550-\mathrm{mZrO}_{2}$ & 2.39 & 0.08 & 0.08 & 1.03 & 0.07 & 0.15 & 14.4 & 4.5 & 9.7 \\
\hline $\mathrm{C} 600-\mathrm{mZrO}_{2}$ & 1.72 & 0.07 & 0.10 & 0.92 & 0.05 & 0.05 & 6.7 & 2.5 & 3.5 \\
\hline $\mathrm{C} 650-\mathrm{mZrO}_{2}$ & 1.10 & 0.08 & 0.10 & 0.90 & 0.03 & 0.02 & 4.6 & 1.0 & 1.2 \\
\hline $\mathrm{C} 550-\mathrm{mZrO}_{2}-\mathrm{S}-1$ & 8.48 & 0.07 & 0.11 & 1.08 & 0.27 & 0.40 & 33.7 & 11.0 & 21.2 \\
\hline $\mathrm{C} 550-\mathrm{mZrO}_{2}-\mathrm{S}-2$ & 7.68 & 0.03 & 0.10 & 1.25 & 0.24 & 0.32 & 32.8 & 13.9 & 17.1 \\
\hline $\mathrm{C} 550-\mathrm{mZrO}_{2}-\mathrm{S}-3$ & 7.26 & 0.05 & 0.09 & 1.44 & 0.23 & 0.33 & 31.8 & 13.6 & 16.3 \\
\hline $\mathrm{C} 600-\mathrm{mZrO}_{2}-\mathrm{S}-1$ & 7.48 & 0.03 & 0.09 & 1.02 & 0.23 & 0.21 & 20.8 & 7.3 & 13.0 \\
\hline $\mathrm{C} 600-\mathrm{mZrO}_{2}-\mathrm{S}-2$ & 5.01 & 0.04 & 0.11 & 1.15 & 0.15 & 0.18 & 23.3 & 11.2 & 10.9 \\
\hline $\mathrm{C} 600-\mathrm{mZrO}_{2}-\mathrm{S}-3$ & 2.58 & 0.03 & 0.10 & 1.17 & 0.10 & 0.20 & 21.1 & 7.4 & 12.6 \\
\hline $\mathrm{C} 650-\mathrm{mZrO}_{2}-\mathrm{S}-1$ & 3.69 & 0.08 & 0.11 & 0.89 & 0.11 & 0.09 & 14.9 & 6.5 & 6.3 \\
\hline $\mathrm{C} 650-\mathrm{mZrO}_{2}-\mathrm{S}-2$ & 1.58 & 0.07 & 0.11 & 1.02 & 0.05 & 0.05 & 13.8 & 9.6 & 3.7 \\
\hline $\mathrm{C} 650-\mathrm{mZrO}_{2}-\mathrm{S}-3$ & 1.42 & 0.06 & 0.09 & 0.96 & 0.04 & 0.05 & 14.1 & 9.9 & 3.4 \\
\hline
\end{tabular}

${ }^{a}$ All calcined materials were calcined with a ramping rate of $0.1{ }^{\circ} \mathrm{C} / \mathrm{min} .{ }^{b}$ The weight losses at $850{ }^{\circ} \mathrm{C}$ in TG analysis. ${ }^{c}$ In the range $\mathrm{RT}-300$ ${ }^{\circ} \mathrm{C}$ in TG analysis. ${ }^{d}$ In the range $600-850{ }^{\circ} \mathrm{C}$ in TG analysis.

the $\mathrm{S} / \mathrm{Zr}$ ratios were $0.10-0.23$ for the $\mathrm{NaCl}$-extracted samples versus 0.05 for the unextracted one. The differences got even closer at a calcination temperature of $650{ }^{\circ} \mathrm{C}$. The formula of the calcined samples can be written as $\mathrm{ZrO}_{2-x}\left(\mathrm{SO}_{4}\right)_{x}$ with $x$ in the range $0.04-0.27$, depending on the number of $\mathrm{NaCl}$ extractions and the calcination temperature. Most of the $x$ values measured by the TG method were consistent with or slightly higher than that of the EA method.

Thermal analysis using a quadruple mass detector for evolved gas analysis was employed to investigate the molecular fragments released during the calcination process. Figure 8 shows the DSC-TG-MS profiles of as-made mesoporous zirconia and that extracted with $\mathrm{NaCl}$ solution three times. The total weight losses are summarized in Table 2. The total weight loss of $\mathrm{mZrO}_{2}$ was ca. 66.2 wt $\%$, and those of $\mathrm{mZrO}_{2}-\mathrm{S}-1, \mathrm{mZrO}_{2}-$ $\mathrm{S}-2$, and $\mathrm{mZrO}_{2}-\mathrm{S}-3$ were $57.3,53.9$, and $48.8 \mathrm{wt} \%$, respectively. Hence, the amounts of surfactant and sulfate extracted from the materials were $8.9,12.3$, and 17.4 wt $\%$ for three different numbers of extraction. Four molecular fragments including $\mathrm{H}_{2} \mathrm{O}, \mathrm{CO}_{2}, \mathrm{SO}$, and $\mathrm{SO}_{2}$ were selected to detect by the mass detector. The mass profiles of water and $\mathrm{CO}_{2}$ in the as-made and $\mathrm{NaCl}$-extracted materials are similar, whereas the profiles of $\mathrm{SO}$ and $\mathrm{SO}_{2}$ for these two samples are very different. The peaks of $\mathrm{SO}$ and $\mathrm{SO}_{2}$ shift toward higher temperatures for the material pre-extracted with $\mathrm{NaCl}$ solution. According to the profiles of $\mathrm{SO}$ and $\mathrm{SO}_{2}$, there are at least two kinds of sulfur species in the as-made mesoporous zirconia. The one that could be removed by $\mathrm{NaCl}$ extraction was of less thermal stability and decomposed at lower temperature, while the other sulfur species, which was not removed by extraction, decomposed at higher temperature.

Figure 9 compares the DSC-TG-MS profiles of $550{ }^{\circ} \mathrm{C}$ calcined mesoporous zirconia materials with and without $\mathrm{NaCl}$ extraction. For the unextracted sample C550- $\mathrm{mZrO}_{2}$, two steps 

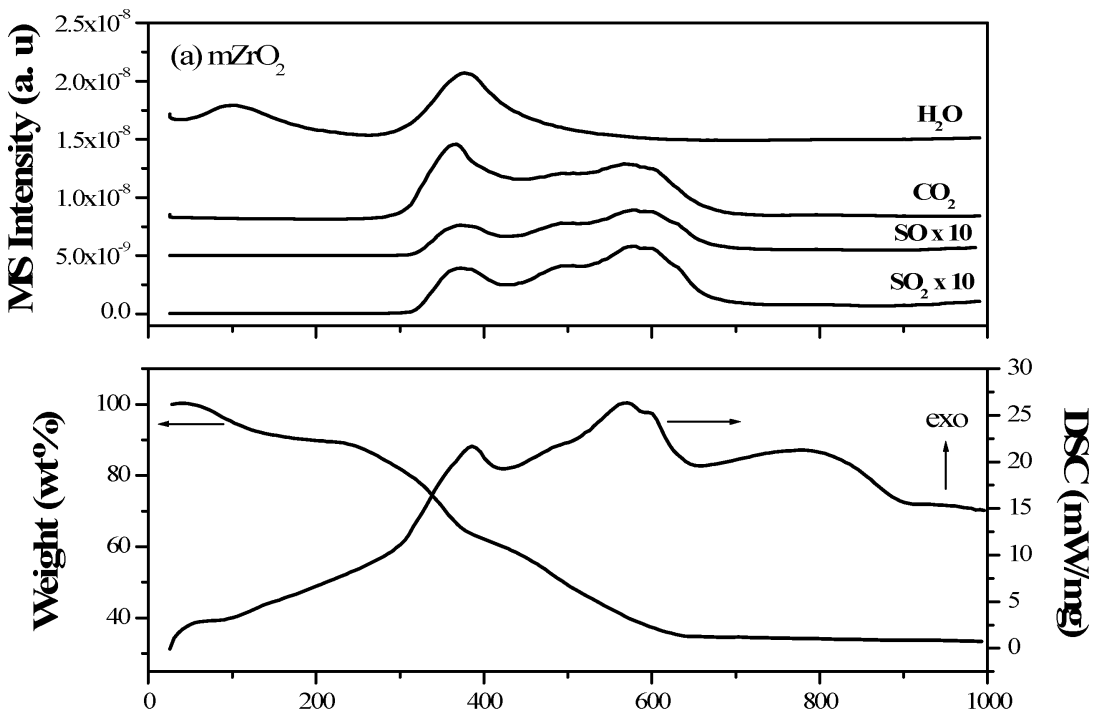

Temperature $\left({ }^{\circ} \mathrm{C}\right)$
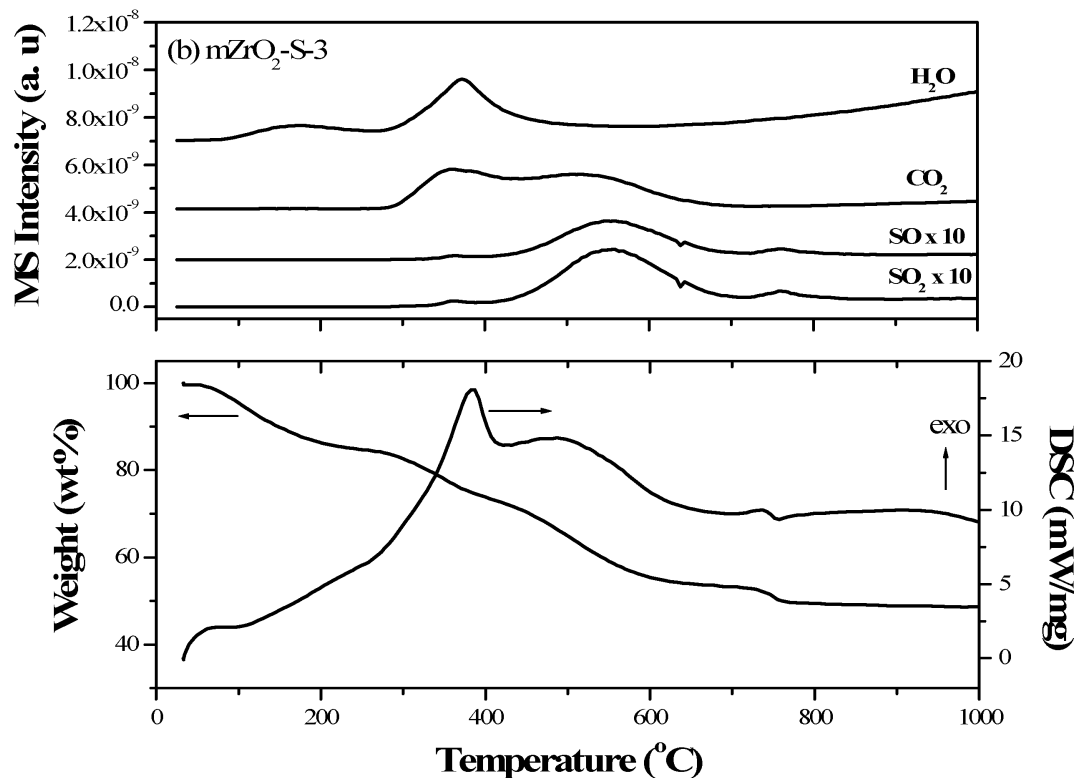

Figure 8. DSC-TG-MS profiles of (a) $\mathrm{mZrO}_{2}$ and (b) $\mathrm{mZrO}_{2}-\mathrm{S}-3$ samples.

of weight losses were observed. The weight loss with a maximum MS intensity at $110^{\circ} \mathrm{C}$ was mainly the release of water. The amount of water released before $250{ }^{\circ} \mathrm{C}$ was calculated to be ca. $4.5 \mathrm{wt} \%$. The other weight loss of ca. 9.8 wt $\%$ (calculated in the $600-850{ }^{\circ} \mathrm{C}$ region) with the maximum MS signal at $700{ }^{\circ} \mathrm{C}$ was assigned to the decomposition of sulfur- and carbon-based species retained in the calcined material. It gave an endothermic peak in the DSC profile. The $\mathrm{NaCl}$-extracted sample $\mathrm{C} 550-\mathrm{mZrO}_{2}-\mathrm{S}-3$ also gave a two-step weight loss. However, both weight losses were greater than those of $\mathrm{C} 550-\mathrm{mZrO}_{2}$ and shifted toward relatively higher temperatures. On the basis of the MS signals, the weight loss at lower temperature was water. The $12.3 \mathrm{wt} \%$ of water released from $\mathrm{C} 550-\mathrm{mZrO}_{2}-\mathrm{S}-3$ was almost 3 times greater than that from the unextracted sample $\mathrm{C} 550-\mathrm{mZrO}_{2}$. These results are consistent with the observation in the IR spectra, which showed that the surface of calcined $\mathrm{mZrO}_{2}-\mathrm{S}-x$ samples was more hydrophilic than that of the unextracted sample. On the other hand, the weight loss at higher temperature was mainly sulfur species, and according to the IR studies shown in Figure 7, the sulfur species in $\mathrm{C} 550-\mathrm{mZrO}_{2}-\mathrm{S}-3$ were predominantly sulfate. These results suggest that post-treatment with $\mathrm{NaCl}$ solution could remove the thermally unstable sulfate groups but retained the thermally stable sulfate groups, which contributed significantly to the thermal stability of the mesoporous structure.

X-ray Absorption Spectroscopy. To understand the role of sulfur species in the thermal stability of the mesoporous $\mathrm{ZrO}_{2}$ materials, sulfur K-edge X-ray absorption near edge structure (XANES) spectra were taken using a continuous X-ray source of synchrotron radiation at beam line 15B of National Synchrotron Radiation Research Center (NSRRC) in Hsinchu, Taiwan. The sulfur K-edge XANES spectra of several sulfurcontaining standards and mesoporous zirconia-based materials are shown in Figure 10. The fresh zirconium sulfate $\mathrm{Zr}\left(\mathrm{SO}_{4}\right)_{2}$ • $4 \mathrm{H}_{2} \mathrm{O}$ was used as received from Aldrich without further purification, and the calcined zirconium sulfate was obtained by heating $\mathrm{Zr}\left(\mathrm{SO}_{4}\right)_{2} \cdot 4 \mathrm{H}_{2} \mathrm{O}$ in air at $550{ }^{\circ} \mathrm{C}$ for $3 \mathrm{~h}$ with a ramp rate of $0.1{ }^{\circ} \mathrm{C} / \mathrm{min}$. Both the fresh and calcined zirconium sulfate samples showed a split absorption peak around 2481.2 and $2481.8 \mathrm{eV}$, respectively. The peak shape and peak width of these two samples are similar. The K-edge absorption is assigned to the electron transition from the $1 \mathrm{~s}$ orbital of sulfur to the predominant $3 p$ energy levels, ${ }^{21}$ and the absorption energy varies with the oxidation state and coordination environment of sulfur. 

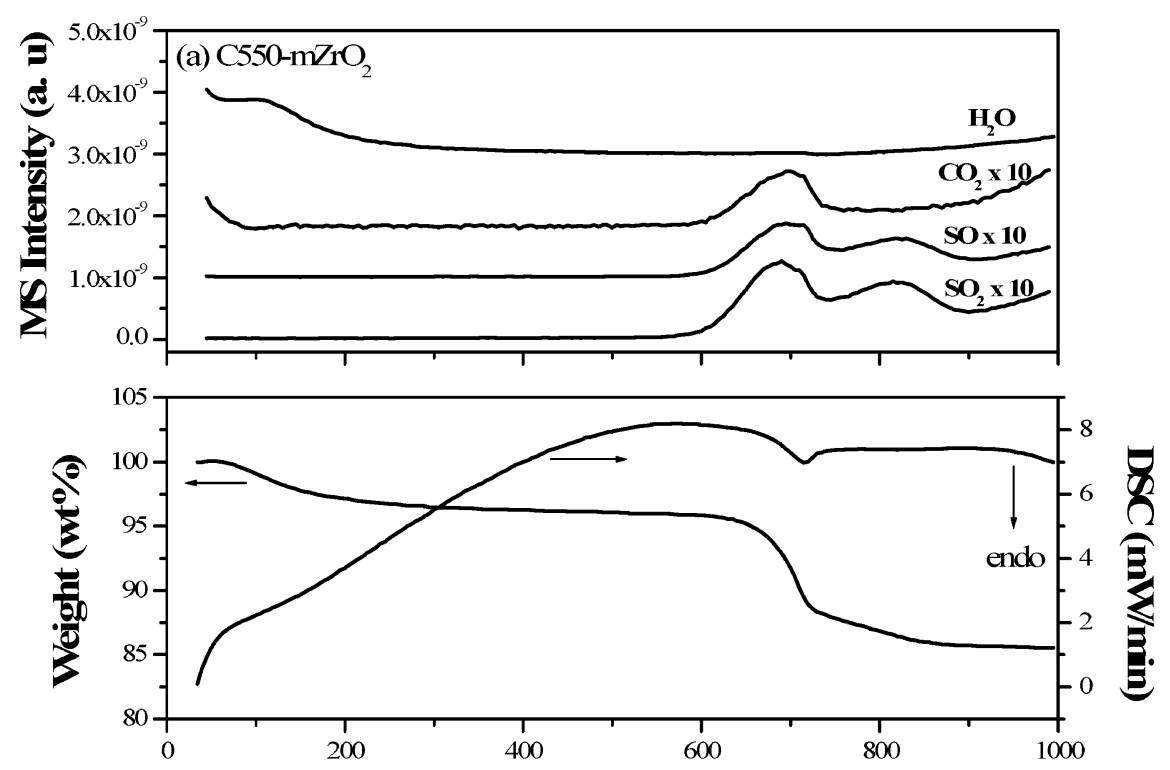

Temperature $\left({ }^{\circ} \mathrm{C}\right)$
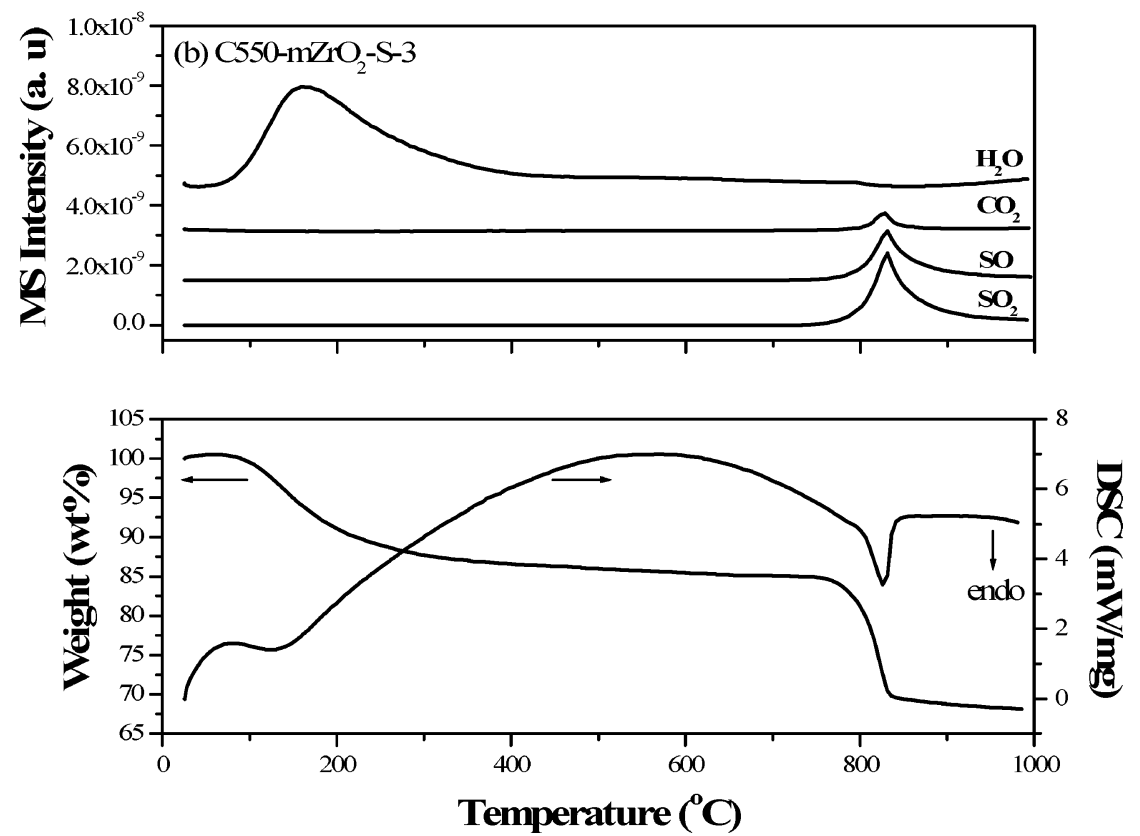

Figure 9. DSC-TG-MS profiles of (a) $\mathrm{C} 550-\mathrm{mZrO}_{2}$ and (b) $\mathrm{C} 550-\mathrm{mZrO}_{2}-\mathrm{S}-3$ samples.

In fresh $\mathrm{Zr}\left(\mathrm{SO}_{4}\right)_{2} \cdot 4 \mathrm{H}_{2} \mathrm{O}$ of antiprism crystal structure, each zirconium is eight-coordinated, with four sulfate groups and four water molecules. Upon heating, $\mathrm{Zr}\left(\mathrm{SO}_{4}\right)_{2} \cdot 4 \mathrm{H}_{2} \mathrm{O}$ was transferred into $\mathrm{Zr}\left(\mathrm{SO}_{4}\right)_{2} \cdot \mathrm{H}_{2} \mathrm{O}$ or $\beta-\mathrm{Zr}\left(\mathrm{SO}_{4}\right)_{2}$ of the same crystal structure. ${ }^{22 \mathrm{a}}$ The sulfur K-edge XANES spectra confirmed that the chemical environments of the sulfur in the zirconium sulfate before and after calcination were similar. The sulfur K-edge XANES spectrum of sodium sulfite showed two absorption peaks at 2476.4 and $2480 \mathrm{eV}$. Because the oxidation state of sulfur in the sulfite ion was +4 lower than that in the sulfate ion, the absorption peaks of sodium sulfite shifted to relatively low energy. ${ }^{22 b, c}$ The sodium thiosulfate showed a much different feature in the XANES region than that of sodium sulfate and sodium sulfite. Four distinguished peaks with absorption energies of ca. 2470.8, 2474.2, 2478, and $2480 \mathrm{eV}$ were found. According to literature reports, ${ }^{25,26}$ these absorption peaks were the mixed contribution of the excitation of outer sulfur $\left(\mathrm{S}^{-}\right.$in the $\mathrm{S}-\mathrm{S}$ environment of the $\mathrm{S}_{2} \mathrm{O}_{3}{ }^{2-}$ ion) and inner sulfur $\left(\mathrm{S}^{5+}\right.$ in the $\mathrm{SO}_{3}$ environment of the $\mathrm{S}_{2} \mathrm{O}_{3}{ }^{2-}$ ion) in the thiosulfate ion.

The sulfur K-edge XANES spectra of as-made zirconia-based mesoporous materials were akin to those of zirconium sulfate, indicating that sulfur was in the form of sulfate ion. However, the calcined materials gave different spectra. In addition to the peak at $2481.8 \mathrm{eV}$, there were additionally two absorption peaks at 2471.6 and $2477 \mathrm{eV}$ when $\mathrm{mZrO}_{2}$ was calcined at $550{ }^{\circ} \mathrm{C}$ with a ramp rate higher than $0.2^{\circ} \mathrm{C} / \mathrm{min}$ (Figure $8 \mathrm{~b}$ ). This implied that a portion of the sulfate ions was likely reduced to lower valence states by hydrogen-rich surfactants during the calcination process. In comparison with the XANES spectra of sulfite and thiosulfate ions, the oxidation state of sulfur was in the range -1 to $+4 .^{23-27}$ The intensity of these peaks decreased when the ramp rate was lowered to $0.1{ }^{\circ} \mathrm{C} / \mathrm{min}$. These results indicate that the reduction of sulfate ions could be minimized by lowering the ramping rate in the calcination process. 


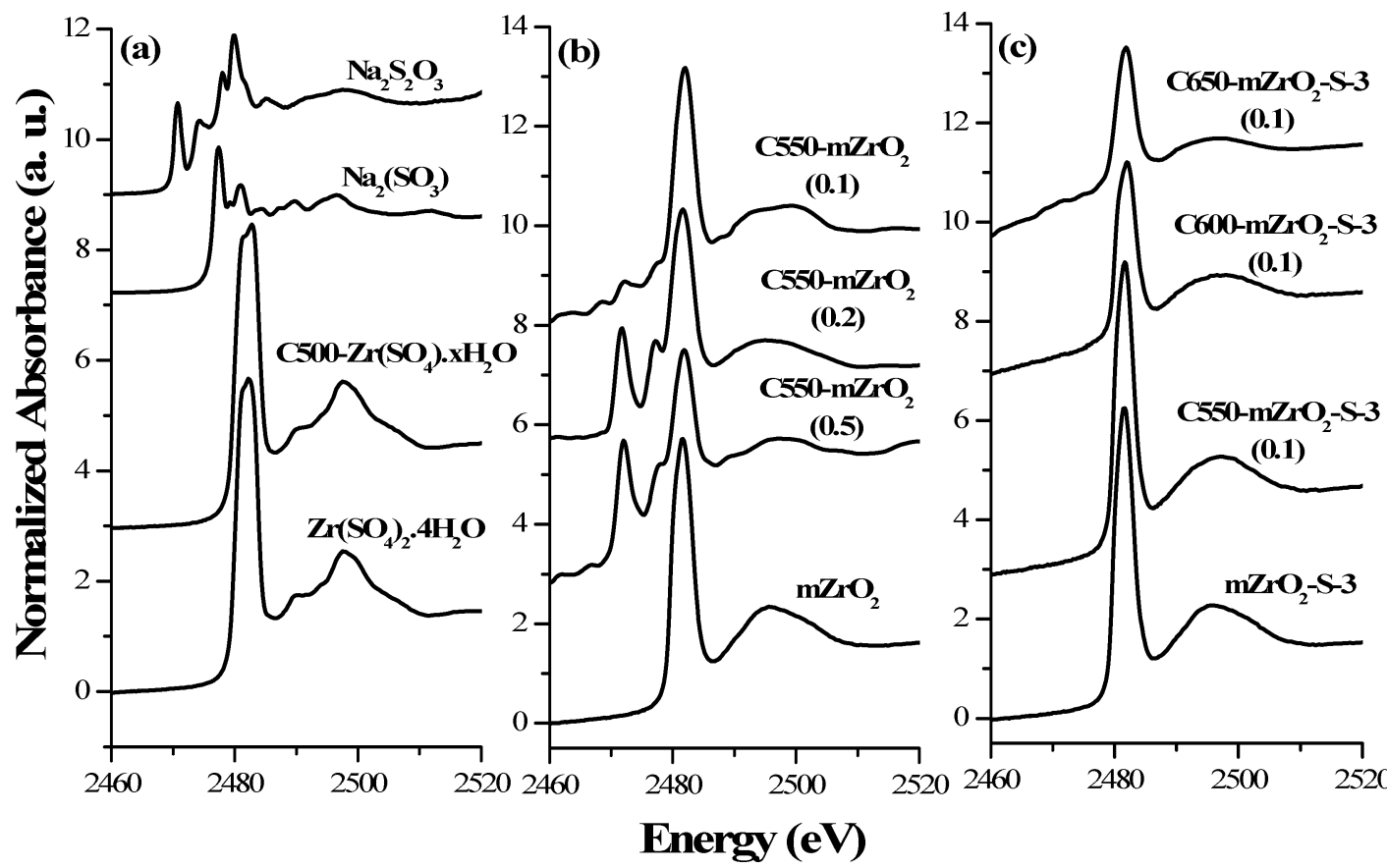

Figure 10. Sulfur K-edge XANES spectra of (a) sulfur standards, (b) $\mathrm{mZrO}_{2}$ and calcined $\mathrm{mZrO}_{2}$, and (c) $\mathrm{mZrO}_{2}-\mathrm{S}-3$ and calcined $\mathrm{mZrO}{ }_{2}-\mathrm{S}-3$, where the numbers in parentheses are the ramping rate at ${ }^{\circ} \mathrm{C} / \mathrm{min}$ in the calcination process.

However, when the unextracted $\mathrm{mZrO}_{2}$ was calcined at temperatures greater than $550{ }^{\circ} \mathrm{C}$, even with a low ramping rate of $0.1{ }^{\circ} \mathrm{C} / \mathrm{min}$, the intensity of the $\mathrm{S} \mathrm{K}$-edge absorption became very weak and only the $2481.8 \mathrm{eV}$ peak was detectable. This result was consistent with that of IR studies, which showed that most of the sulfate groups were removed at temperatures higher than $550{ }^{\circ} \mathrm{C}$.

For the mesoporous zirconia material extracted with $\mathrm{NaCl}$ solution two or three times, the sulfur K-edge XANES spectra showed only one peak at $2481.8 \mathrm{eV}$, independent of calcination temperature (Figure 8c). No sulfur species of lower valence states were observed. This indicates that the chemical environment of sulfur in the calcined $\mathrm{mZrO}_{2}-\mathrm{S}-x$ samples was kept in the form of sulfate ions. They were not reduced by the hydrogenrich surfactant molecules during the calcination process. It was also noticed that the ramping rate in the calcination process had no effect on the chemical environment of sulfur in the calcined $\mathrm{mZrO}_{2}-\mathrm{S}-x$ samples, which were extracted with $\mathrm{NaCl}$ solution. On the basis of these results, it was concluded that the retaining of a proper amount of sulfate groups in the material without reduction was the key to prepare mesoporous $\mathrm{ZrO}_{2}$ of high stability.

\section{Conclusions}

Highly ordered zirconia-based mesoporous materials were prepared by using zirconium sulfate as the zirconium source and CTMA ion as the pore-directing agent with the aid of $\mathrm{NaCl}$ salt. The as-made material was found to contain sulfur in the form of sulfate with a $\mathrm{S} / \mathrm{Zr}$ molar ratio around 0.5 . A posttreatment process including $\mathrm{NaCl}$ extraction prior to calcination and lowering the ramping rate (less than $0.2^{\circ} \mathrm{C} / \mathrm{min}$ ) in the calcination process was developed to prepare highly ordered zirconia-based mesoporous materials with thermal stability up to $600{ }^{\circ} \mathrm{C}$. By using $0.5 \mathrm{M} \mathrm{NaCl}$ solution as the extracting agent, $8.9-17.4$ wt $\%$ of the surfactants and $0.5-1.2$ wt $\%$ of sulfate groups were removed. On the basis of the sulfur K-edge XANES, IR, and DSC-TG-MS studies, the extraction removed the thermally unstable sulfate groups and prevented the remain- ing sulfate groups from being reduced by hydrogen-rich surfactant during the calcination process, which seemed to be important in retaining the ordered mesostructure of zirconia. Based on the elemental analysis, the composition of calcined zirconia-based mesoporous materials was $\mathrm{ZrO}_{2-x}\left(\mathrm{SO}_{4}\right)_{x}$ with $x$ $=0.10-0.27$, depending on the number of $\mathrm{NaCl}$ extractions and the temperature of calcination. They possessed high surface area $\left(\sim 200 \mathrm{~m}^{2} / \mathrm{g}\right)$, large pore volume $\left(\sim 0.10 \mathrm{~cm}^{3} / \mathrm{g}\right)$, and mesopore diameter $(1.5-3.0 \mathrm{~nm})$ with a $1-1.5 \mathrm{~nm}$ wall thickness. In comparison with the phosphate-stabilized zirconia mesoporous materials prepared by post-treatment of mesoporous zirconia material with phosphoric acid solution and other methods reported in the literature, the post-treatment route developed in the present study was very simple and environmentally friendly.

Acknowledgment. The authors thank CTCI Foundation and National Science Council, Taiwan, for the financial support. Acknowledgments are also extended to Mr. C.-Y. Tang, Ms. C.-Y. Lin, Ms. C.-W. Lu, and Mr. C.-S. Kao of Instrumentation Center of National Taiwan University for the assistance in TEM, SEM, and EDS experiments, elemental analysis, and thermal analysis.

\section{References and Notes}

(1) (a) Kordesch, K.; Simader, G. Fuel Cells and Their Applications; VCH Publishers: New York, 1996; p 137. (b) Ormerod, R. M. Chem. Soc. Rev. 2003, 32, 17.

(2) Tanabe, K.; Yamaguchi, T. Catal. Today 1994, 20, 185.

(3) (a) Kresge, C. T.; Leonowicz, M. E.; Roth, W. J.; Vartuli, J. C.; Beck, J. S. Nature 1992, 359, 710. (b) Beck, J. S.; Vartuli, J. C.; Roth, W. J.; Leonowicz, M. E.; Kresge, C. T.; Schmitt, K. D.; Chu, C. T. W.; Olson, D. H.; Sheppard, E. W.; Mccullen, S. B.; Higgins, J. B.; Schlenker, J. L. J. Am. Chem. Soc. 1992, 114, 10834. (c) Lin, H. P.; Mou, C. Y. Acc. Chem. Res. 2002, 35927.

(4) (a) Tanev, P. T.; Pinnavaia, T. J. Science 1995, 267, 865. (b) Bagshaw, S. A.; Prouzet, E.; Pinnavaia, T. J. Science 1995, 269, 1242.

(5) (a) Zhao, D. Y.; Feng, J.; Huo, Q.; Melosh, N.; Fredrickson, G. H.; Chmelka, B. F.; Stucky. G. D. Science 1998, 279, 548. (b) Zhao, D. Y.; Huo, Q. S.; Feng, J. L.; Chmelka, B. F.; Stucky, G. D. J. Am. Chem. Soc. 1998, 120, 6024. 
(6) (a) Knowles, J. A.; Hudson, M. J. J. Chem. Soc., Chem. Commun. 1995, 20, 2083. (b) Hudson, M. J.; Knowles, J. A. J. Mater. Chem. 1996 6,89 .

(7) (a) Antonelli, D. M.; Ying, J. Y. Angew. Chem., Int. Ed. Engl. 1995 34, 2014. (b) Antoneli, D. M.; Ying J. Y. Angew. Chem., Int. Ed. Engl. 1996, 35, 426. (c) Wong, M. S.; Antonelli, D. M.; Ying, J. Y. Nanostruct. Mater. 1997, 9, 165. (d) Wong, M. S.; Ying, J. Y. Chem. Mater. 1998, 10, 2067. (e) Ying, J. Y.; Mehnert, C. P.; Wong, M. S. Angew. Chem., Int. Ed. 1999, $38,56$.

(8) (a) Ciesla, U.; Schacht, S.; Stucky, G. D.; Unger, K.; Schüth, F. Angew. Chem., Int. Ed. Engl. 1996, 35, 541. (b) Ciesla, U.; Fröba, M.; Stucky, G. D.; Schüth, F. Chem. Mater. 1999, 11, 227. (c) Linden, M.; Blanchard, J.; Schacht, S.; Schunk, S. A.; Schüth, F. Chem. Mater. 1999, 11, 3002. (d) Kleitz, F.; Thomson, S. J.; Liu, Z.; Terasaki, O.; Schüth, F. Chem. Mater. 2002, 14, 4134.

(9) (a) Shen, S. D.; Tian, B. Z.; Yu, C. Z.; Xie, S. H.; Zhang. Z. D.; Tu, B.; Zhao, D. Y. Chem. Mater. 2003, 15, 4046. (b) Wu, P.; Liu, Y. M.; He, M. Y.; Iwamoto, M. Chem. Mater. 2005, 17, 3921.

(10) (a) Parvulescu, V. I.; Bonnemann, H.; Parvulescu, V.; Endruschat, U.; Rufinska, A.; Lehmann, C. W.; Tesche, B.; Poncelet, G. Appl. Catal. A 2001, 214. 273. (b) Parvulescu, V. I.; Parvulescu V.; Endruschat, U.; Lehmann, C. W.; Grange, P.; Poncelet, G.; Bonnemann, H. Microporous Mesoporous Mater. 2001, 44, 221.

(11) De Bruyn, M.; Limbourg, M.; Denayer, J.; Baron, G. V.; Parvulescu, V.; Grobet, P. J.; De Vos, D. E.; Jacobs, P. A. Appl. Catal. A 2003, 254, 189.

(12) Lyu, Y. Y.; Yi, S. H.; Shon, J. K.; Chang, S.; Pu, L. S.; Lee, S. Y.; Yie, J. E.; Char, K.; Stucky, G. D.; Kim, J. M. J. Am. Soc. Chem. 2004, 8, 2310 .

(13) Crepaldi, E. L.; Soler-Illia, G. J. de A. A.; Grosso, D.; Albouy, P.-A.; Sanchez, C. Chem. Commun. 2001, 1582.

(14) Pacheco, G.; Zhao, E.; Garcia, A.; Sklyarov, A.; Fripiat, J. J. Chem. Commun. 1997, 491.

(15) Kim, A.; Bruinsma, P.; Chen, Y.; Wang, L.; Liu, J. Chem. Commun. 1997, $161-162$.
(16) Cassiers, K.; Linssen, T.; Aerts, K.; Cool, P.; Lebedev, O.; Tendeloo, G. V.; Grieken, R. V.; Vansant, E. F. J. Mater. Chem. 2003, 13, 3033.

(17) Das, D.; Tsai, C. M.; Cheng, S. Chem. Commun. 1999, 473-474.

(18) (a) Wang, Y. Q.; Yang, C. M.; Zibrowius, B.; Spliethoff, B.; Linden, M.; Schuth, F. Chem. Mater. 2003, 15, 5029. (b) Chen, S. Y.; Jang, L. Y. Cheng, S. Chem. Mater. 2004, 16, 4174-4180. (c) Chen, S. Y.; Cheng, S. Stud. Surf. Sci. Catal. 2005, 156, 90.

(19) (a) Yang, C. M.; Zibrowius, B.; Schmidt, W.; Schüth, F. Chem. Mater. 2003, 15, 3739. (b) Wang, X.; Chen, C. C.; Chen, S. Y.; Mou, Y.; Cheng, S. Appl. Catal. A 2005, 281, 47. (c) Wang, X.; Lin, K. S. K.; Chan, J. C. C.; Cheng, S. J. Phys. Chem. B 2005, 109, 1763.

(20) (a) Sokolov, I.; Yang, H.; Ozin, G. A.; Kresge, C. T. Adv Mater. 1999, 11, 636-642. (b) Inagaki, S.; Guan, S.; Fukushima, Y.; Ohsuna, T.; Terasaki, O. J. Am. Chem. Soc. 1999, 121, 9611-9614.

(21) (a) Teo, B. K.; Joy, D. C. EXAFS Spectroscopy, Techniques and Applications; Plenum Press: New York, 1981. (b) Teo, B. K. EXAFS: Basic Principles and Data Analysis; Springer-Verlag: Berlin, 1986. (c) West, A. R. Basic Solid Sate Chemistry, 2nd ed.; Wiley-VCH: New York, 1999; pp 189-196.

(22) (a) Wells, A. F. Structural Inorganic Chemistry, 5th ed.; Oxford University Press, 1984; pp 333-336 and 644-645. (b) Miessler, G. L.; Tarr, D. A. Inorganic Chemistry, 2nd ed.; Prentice Hall: Upper Saddle River, NJ, 1999; pp 164-165. (c) Shriver, D. F.; Atkins, P. W. Inorganic Chemistry, 3rd ed.; Oxford University Press, 1999; p 152.

(23) Das, D.; Lee, J. F.; Cheng, S. Chem. Commun. 2001, 2178.

(24) Pickering, I. J.; George, G. N.; Yu, E. Y.; Brune, D. C.; Tuschak, C.; Overmann, J.; Beatty, J. T.; Prince, R. C. Biochemistry 2001, 40, 8138.

(25) McKeown, D. A.; Muller, I. S.; Gan, H.; Pegg, I. L., Stolte, W. C. J. Non-Cryst. Solids 2004, 333, 74.

(26) Vairavamurthy, A. Spectrochim. Acta, Part A 1998, 54, 2009.

(27) Pickering, I. J.; Prince, R. C.; Divers, T.; George, G. N. FEBS Lett. 1998, 441, 11. 